\title{
Evaluation of Water Quality and The Efficiency of Ifraz-2 Water Treatment Plant-Units
}

\section{Imad Ali Omar}

Department of Civil Engineering, College of Engineering, Salahaddin University-Erbil-Iraq eng_emad_75@yahoo.com

\section{Shuokr Qarani Aziz}

Department of Civil Engineering, College of Engineering, Salahaddin University-Erbil-Iraq shoker71@yahoo.com

\begin{abstract}
:
Water treatment plant (WTP) is essential for providing clean and safe water to the habitants. There is a necessity to evaluate the performance of (WTP) for proper treatment of raw water. The purpose of the present study is to evaluate the quality of treated water by investigating the performance of Ifraz-2 (WTP) units located in Erbil City, Iraq. For assessment of the (WTP) units, samples were taken for a duration of five months from different locations: raw water (the source), post-clarification processes, post-filtration processes, and from the storage tank. Removal efficiencies for the units, and for the whole (WTP) were calculated and presented. Obtained removal efficiencies for the sedimentation unit; filtration unit; and the entire Ifraz-2 (WTP) were $91.51 \%, 64.71 \%$, and $97.29 \%$, respectively. After the process of disinfection and storage, the valued of the turbidity of the treated water were ranged from 1.2 to 9.7 (Nephelometric Turbidity Units) NTU. Besides, water quality index (WQI) for the (WTP) was studied and calculated for 14 physicochemical water quality parameters. WQI for Ifraz-2 (WTP) was 51.87 and it is regarded as a good level. Also, operational problems have been detected and reported during the research period, especially during sedimentation, filtration, and disinfection. Suitable solutions have been reported to the operational team.
\end{abstract}


Keywords: Water treatment plant, Drinking water, Turbidity, Performance, Evaluation, Improvement, Ifraz 2 (WTP).

\section{Introduction}

Drinking water is the most important natural resource as only less than $1 \%$ of the total water on the planet is potable and accessible. Sustained supply of safe and potable drinking water is of paramount significance in the promotion of health and well-being of the people (Khan and Ahmad, 2018). The great civilization from the ancient time was build-up close to or along with sources of water, it indicates the importance of water (Toma, 2013).

(WTP) can be defined as the processes to achieve a water quality that meets specified goals or standards set by the end user or a community through its regulatory agencies. The development of (WTP) practice has a rich history of empirical and scientific developments and challenges met and overcome (Crittenden et al., 2012). Most current drinking (WTP)s use conventional treatment methods like coagulation-flocculation, sedimentation, sand filtration, and disinfection to produce fresh potable water (Frank, 2003; Doosti et al., 2012). Quality of water system used to be analyzed through an intake, raw water, treatment, and transmission. Every treatment plant for proper treatment it needs to consider unit operations unit processes depending upon the raw water quality. Further proper operation and maintenance should be done (Hussain et al., 2011). The performance evaluation of a (WTP) is a process to measure the functioning efficiencies based on some established performance indicators such as a degree of removal of pollutants such as turbidity, color, suspended impurities etc. (Vieira et al., 2008). Treatment or purification of water is considered as an essential facility to conserve both the public health and environment by eliminating waterborne diseases and pathogens (Issa, 2017). The most common problems in drinking (WTP)s are non-optimized use of chemicals, the operation of unit processes, sludge production, and energy consumption. In spite of this, the traditional approach for (WTP) efficiency evaluation is almost always based solely on legislation compliance of the treated water (Vieira et al., 2008).

Kurdistan Region in Iraq (KRI) has rapid growth in population. Effective management of water resources through legislative control on water quality is currently being restricted by a lack of national water quality guidelines (Shareef and Muhamad, 2008). Erbil City is currently served by two water resources; groundwater and surface water. There are four (WTP)s on Greater-Zab river, three of them at Ifraz village providing with 
about $60 \%$ of the total drinking water consumed in Erbil City (EWD, 2019). Due to some daily problems in operation and maintenance of these (WTP), a clear need, therefore, exists for research to focus on detailing performance assessment system for treatment plants. This study focuses on identifying the troubleshoots by evaluation of the performance efficiency of each unit by analyzing inlet and outlet samples and assess actual performance of Ifraz 2 (WTP) units. This type of efficiency performance evaluation, analyzing Ifraz 2 (WTP) units, and calculating water quality index (WQI) for Ifraz-2 (WTP), and identifying the problems then reporting a suitable appropriate solutions have not been published.

\section{Materials and Methods}

\subsection{Site Description}

Erbil City is the capital of Kurdistan region located $350 \mathrm{~km}$ North of Baghdad. The Population of Erbil City is estimated as based on population data of Central Statistical Office (CSO). Currently, the population is estimated to be 1365000 persons and is rapidly developing with annual growth rate of 3.5\% (Erbil CSO). Its boundaries extended from longitude $43^{\circ} 15^{-} \mathrm{E}$ to $45^{\circ} 14^{-} \mathrm{E}$ and from latitude $35^{\circ} 27^{-} \mathrm{N}$ to $37^{\circ} 24^{-} \mathrm{N}$ (Shareef and Muhamad, 2008). Erbil city is currently served by two main types of water resources, groundwater and surface water. There are about 800 deep wells served in Erbil city and they produce about $40 \%$ of the total demand for drinking water (EWD, 2019). However, surface water is the second significant source of drinking water in Erbil city. There are four (WTP)s on Greater-Zab River, three of them produce drinking water to Erbil City with about $60 \%$ of the total drinking water consumed in Erbil city (EWD, 2019). Three (WTP)s were constructed on Greater-Zab river at Ifraz village, Figure 1. 


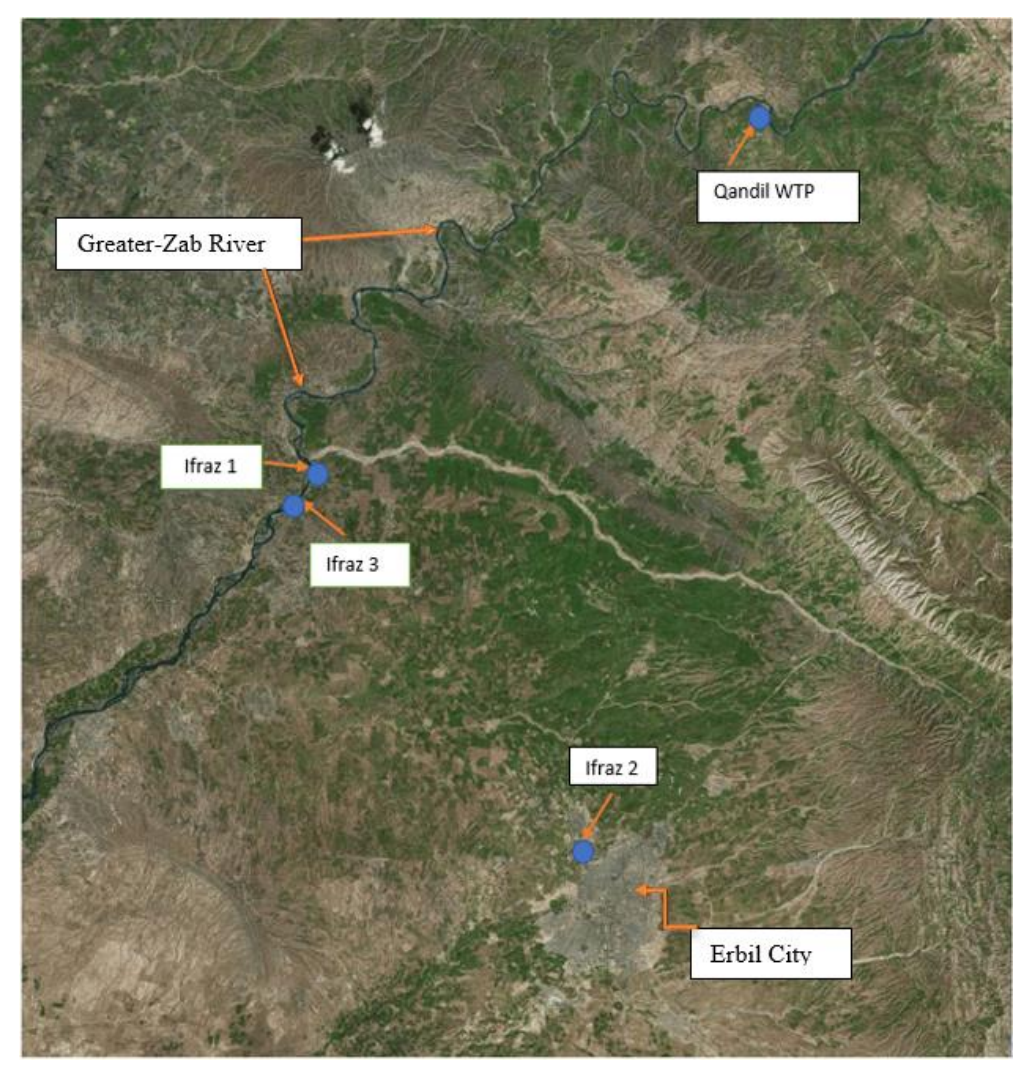

Figure 1: (WTP)s on Greater-Zab Rive

\subsection{Sample Collection}

Water samples were collected from raw water, after sedimentation, after filtration, and after disinfection, the samples were collected between 9 to 11 am as shown in Table 1 in $500 \mathrm{ml}$ glass bottles in the locations as shown in Figure 2. All samples have taken in Erbil (WTP), the raw water samples collected at the inlet of the trunk main at Erbil (WTP). The samples were collected and analyzed according to APHA (2005) in Erbil Water Directorate Laboratory. Removal efficiencies for the (WTP) units were calculated according to the equation:

Removal efficiency $=\left(\mathrm{C}_{\mathrm{o}}-\mathrm{C}_{\mathrm{f}}\right) / \mathrm{C}_{\mathrm{o}} * 100 \quad \ldots$ (1)

Where: -

$\mathrm{C}_{\mathrm{o}}=$ Turbidity of the water sample before treatment, NTU.

$\mathrm{C}_{\mathrm{f}}=$ Turbidity of the water sample after treatment, NTU. 


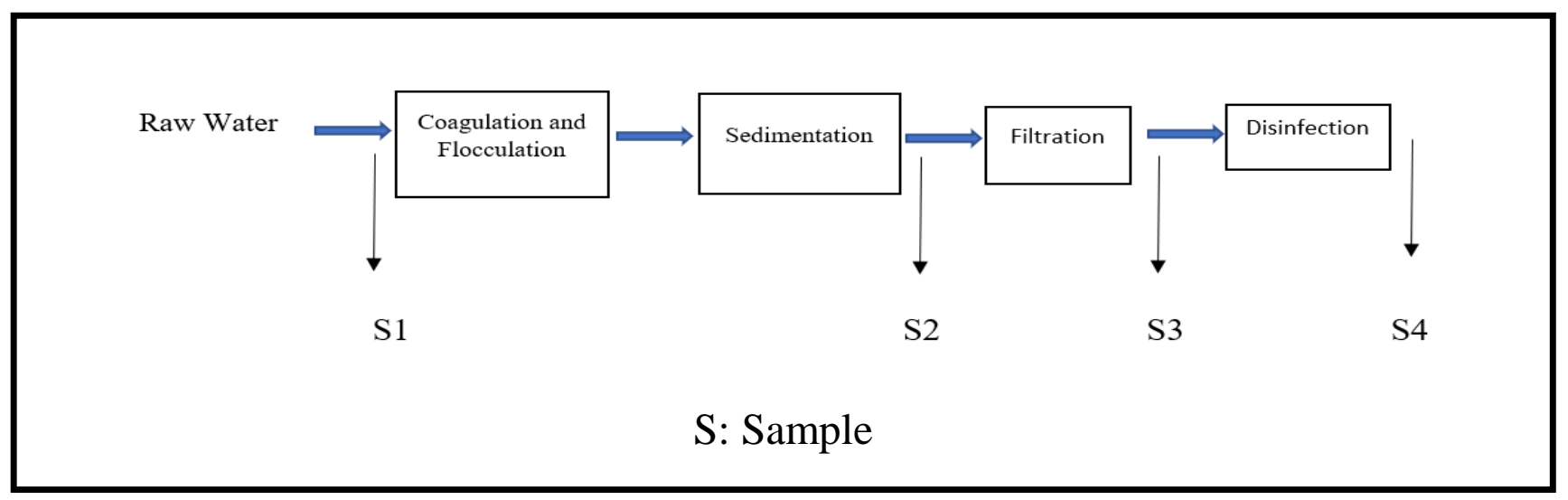

Figure 2: Location of the Samples

\subsection{Water Quality Index}

An average of two set of samples per month were collected from November 2018 to March 2019, for Ifraz-2 (WTP). The samples of raw water and clean water were collected in plastic containers and immediately transported to the Laboratory. They were stored in the refrigerator at $4{ }^{\circ} \mathrm{C}$ before experimental use to prevent biological activities and changes in their characteristics (APHA, 2005). The collected treated samples were analyzed for 14 water-quality parameters. These parameters were as follows: Turbidity (NTU), pH, electrical conductivity $(\mathrm{EC})(\mu \mathrm{s} / \mathrm{cm})$, total dissolved salts $(\mathrm{TDS})(\mathrm{mg} / \mathrm{L})$, total alkalinity $(\mathrm{mg} / \mathrm{L})$, total hardness $(\mathrm{mg} / \mathrm{L})$, calcium $(\mathrm{mg} / \mathrm{L})$, chloride $(\mathrm{mg} / \mathrm{L})$, Sulphate $\left(\mathrm{SO}_{4}\right)(\mathrm{mg} / \mathrm{L})$, sodium $(\mathrm{Na})(\mathrm{mg} / \mathrm{L})$, magnesium $(\mathrm{mg} / \mathrm{L})$, nitrate $\left(\mathrm{NO}_{3}\right)(\mathrm{mg} / \mathrm{L})$, and Total coliform $(\mathrm{MPN} / 100 \mathrm{ml})$, Table 1. The experiments were conducted in the Erbil Water Directorate Laboratory, Erbil, Iraq.

For computing water quality index three steps are followed as. In the first step, each of the 14 parameters has been assigned a weight (wi) according to its relative importance in the overall quality of water for drinking purposes. The maximum weight of 5 has been assigned to parameters like turbidity, chloride, nitrate, and total coliform due to their major importance in water quality assessment. The parameters like $\mathrm{pH}, \mathrm{EC}$, TDS, Total alkalinity, Total hardness, $\mathrm{Ca}, \mathrm{Mg}, \mathrm{Na}, \mathrm{K}$, and $\mathrm{SO}_{4}$ were assigned a weight between 1 and 5 depending on their importance in the overall quality of water for drinking purposes (Sefie et al., 2018).

In the second step, the relative weight (Wi) is computed from the following equations:

$$
W i=\frac{w i}{\sum w i}
$$


Table.1 Details of water parameters with their weight and drinking water standards

\begin{tabular}{|c|c|c|c|c|c|}
\hline Parameters & Unit & $\begin{array}{c}\text { Actual } \\
\text { mean } \\
\text { value }\end{array}$ & $\begin{array}{c}\text { Water Quality } \\
\text { Standard }\end{array}$ & Weight (wi) & $\begin{array}{c}\text { Relative weight } \\
\text { (Wi) }\end{array}$ \\
\hline Turbidity & $\mathrm{NTU}$ & 4.590 & 5 & 5 & 0.093 \\
\hline $\mathrm{pH}$ & - & 7.420 & 8 & 3 & 0.056 \\
\hline $\mathrm{EC}$ & $\mu \mathrm{s} / \mathrm{cm}$ & 419.100 & 1000 & 4 & 0.074 \\
\hline $\mathrm{TDS}$ & $\mathrm{mg} / \mathrm{L}$ & 272.415 & 500 & 5 & 0.093 \\
\hline $\mathrm{T} . \mathrm{Alkalinity}$ & $\mathrm{mg} / \mathrm{L}$ & 206.200 & 200 & 3 & 0.056 \\
\hline $\mathrm{T} . \mathrm{Hardness}$ & $\mathrm{mg} / \mathrm{L}$ & 306.100 & 200 & 3 & 0.056 \\
\hline $\mathrm{Ca}$ & $\mathrm{mg} / \mathrm{L}$ & 76.500 & 100 & 3 & 0.056 \\
\hline $\mathrm{CI}$ & $\mathrm{mg} / \mathrm{L}$ & 14.5000 & 250 & 5 & 0.093 \\
\hline $\mathrm{SO} 4$ & $\mathrm{mg} / \mathrm{L}$ & 37.1000 & 250 & 4 & 0.074 \\
\hline $\mathrm{Mg}$ & $\mathrm{mg} / \mathrm{L}$ & 55.104 & 30 & 3 & 0.056 \\
\hline $\mathrm{Na}$ & $\mathrm{mg} / \mathrm{L}$ & 18.300 & 200 & 4 & 0.074 \\
\hline $\mathrm{K}$ & $\mathrm{mg} / \mathrm{L}$ & 1.390 & 10 & 2 & 0.037 \\
\hline $\mathrm{NO}$ & $\mathrm{mg} / \mathrm{L}$ & 7.398 & 50 & 5 & 0.093 \\
\hline Total Coliform & $(\mathrm{MPN} / 100 \mathrm{ml})$ & 0.00 & 0 & 5 & 0.093 \\
\hline
\end{tabular}

* WHO (2011)

In the third step, a quality rating scale (Qi) for each parameter is assigned by dividing its concentration in each water sample by its respective standard according to the guidelines laid down by WHO, (2011) and the result for the same is multiplied by 100 (Equation 3).

$\mathrm{Qi}=\left(\frac{C_{i}}{S_{i}}\right) \times 100$

Where, $\mathrm{Qi}=$ the quality rating, $\mathrm{Ci}=$ value of the water quality parameter obtained from the laboratory analysis, $\mathrm{Si}=$ value of the water quality parameter obtained from recommended WHO or Iraqi standard of corresponding parameter.

While the sub-index water quality for $\mathrm{pH}\left(\mathrm{Q}_{\mathrm{pH}}\right)$ was calculated on the basis of the following relation.

$\mathrm{Qi}=[(\mathrm{V}$ actual $-\mathrm{V}$ ideal $) /(\mathrm{V}$ standard $-\mathrm{V}$ ideal $)] * 100 \quad \ldots$ (4)

Where, Qi = Quality rating of ith parameter for a total of $\mathrm{n}$ water quality parameters $\mathrm{V}$ actual = Actual value of the water quality parameter obtained from laboratory analysis.

V ideal $=$ Ideal value of that water quality parameter can be obtained from the standard Tables.

$\mathrm{V}$ ideal for $\mathrm{pH}=7$ and for other parameters it is equaling to zero (WHO, 2011). 
Equations 3 and 4 ensures that $\mathrm{Qi}=0$ when a pollutant is totally absent in the water sample and $\mathrm{Q} i=100$ when the value of this parameter is just equal to its permissible value. Thus the higher the value of Qi is, the more polluted is the water (Toma, 2013).

For computing the WQI, the SI is first determined for each chemical parameter, which is then used to determine the WQI as per the following Equations (5 and 6).

$\mathrm{SI}_{\mathrm{i}}=\mathrm{W}_{\mathrm{i}} \times \mathrm{Q}_{\mathrm{i}}$

$\mathrm{WQI}=\Sigma \mathrm{SI} i$

The computed WQI values are classified into five categories as explained in Table 2.

Table 2: WQI range and percentage of different water type (Ramakrishnaiah et al., 2009)

\begin{tabular}{|c|c|}
\hline WQI levels & Water Quality \\
\hline$<50$ & Excellent \\
\hline $50.1-100$ & Good \\
\hline $100.1-200$ & Poor \\
\hline $200.1-300$ & Very poor (bad) water \\
\hline$>300$ & Unsuitable (unfit) for drinking \\
\hline
\end{tabular}

\section{Results and Discussions}

\subsection{Plant Description}

Ifraz 2 (WTP) is providing drinking water to a part of Erbil, Figure 3. It is E and N values are $43^{\circ} 59^{\prime} 44^{\prime \prime}$ and $36^{\circ} 12^{\prime} 58^{\prime \prime}$. The plant was constructed in 1983 . The capacity of the plant is $69120 \mathrm{~m}^{3} / \mathrm{d}$, but now it supplies bout $48000 \mathrm{~m}^{3} / \mathrm{d}$ (EWD, 2019). Raw water from Greater-Zab River pumped to Ifraz 2 (WTP) by $800 \mathrm{~mm}$ steel pipe. The length of the pipe from the intake on the Greater-Zab River to the Ifraz 2 (WTP) is $27.65 \mathrm{~km}$. The plant did not have any expansion since first construction, but some rehabilitation/modification for the filtration unit in 2009 and providing grit chamber for the intake part in 2011 were performed (EWD, 2019). 


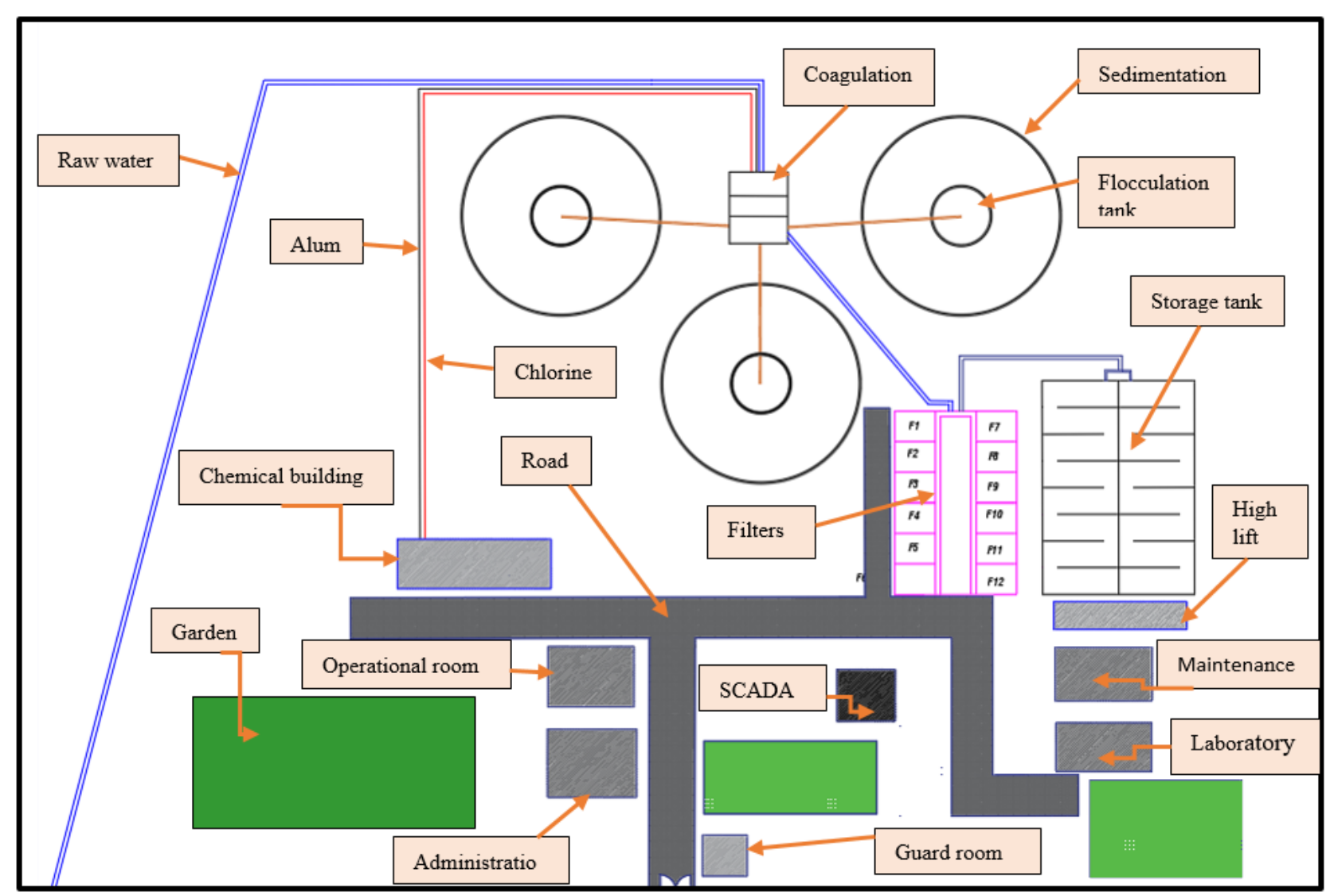

Figure 3: Ifraz 2 (WTP) site

\subsection{Description of the Treatment plant}

\subsubsection{Intake Structure}

The first step in the treatment of water is to remove floating or suspended debris and living organisms, possibly including fish (Aziz, 2009). Intakes are structures built in a body of water for the purpose of drawing water for human use (Foellimi, 2004). It locates at Ifraz villages, it is $\mathrm{E}$ and $\mathrm{N}$ values are $43^{\circ} 48^{\prime} 52^{\prime \prime}$ and $36^{\circ}$ 24' 24", Figure 4. A bar screen and four pipes (two pipes of $250 \mathrm{~mm}$ diameter, and the two remain pipes with a diameter of $300 \mathrm{~mm}$ sucks raw water from Greater-Zab river to the grit chamber). The discharge for the first group and second group submersible pumps are $720 \mathrm{~m}^{3} / \mathrm{h}$ and $1440 \mathrm{~m}^{3} / \mathrm{h}$, respectively. Head of submersible pumps is $10 \mathrm{~m}$. Low lift pumps consist of six pumps. Flow and head for the low lift pumps are $720 \mathrm{~m}^{3} / \mathrm{h}$ and $210 \mathrm{~m}$, respectively. 


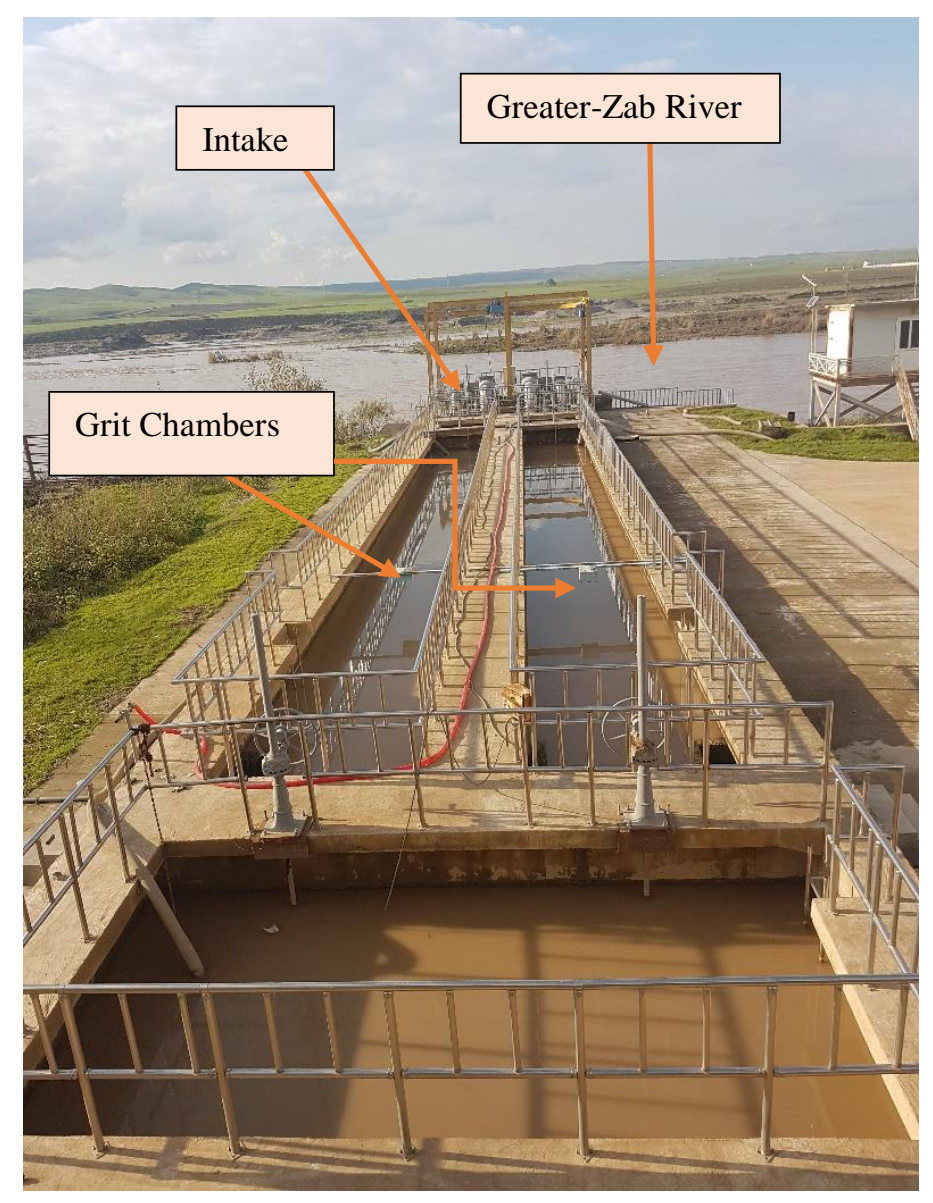

Figure 4: Water intake of Ifraz 2 (WTP) on Greater-Zab River

\subsubsection{Coagulation Processes}

Coagulation is pronounced as a chemical treatment process that mix coagulating chemicals with water and destabilizes colloidal particles as opposed to the physical treatment operations of flocculation and filtration that follow (Aziz, 2009). It is the first treatment for incoming raw water. In this stage alum (aluminum sulfate) is added at highest mixing speed (100) rpm, mixing by rotating mixing paddles to the flow of water. Several factors affect the type and amount of coagulating chemicals required, including the nature of suspended solids and the chemical characteristics of the influent water (Baruth, 2005). The amount of added alum depends on raw water turbidity and the result of Laboratory Daily Jar test. The dimensions for the coagulation tank are 3 x 4 x 5 m (EWD, 2019). 


\subsubsection{Flocculation Process}

Flocculation may be broadly described as physical processes that mix coagulating chemicals and flocculation aids with water (Delphos and Wesner, 2005). Flocculation is gathering small particles and forms a bigger settable particle. The largely formed particle calls floc (Wang et al., 2005). The time requirements for flocculation are more dependent on the requirements of downstream processes. For conventional treatment where settling follows flocculation, the flocculation time ranges from 20 to 30 minutes (Davis, 2010). In Ifraz-2 (WTP), three clarifiers with flocculation inside the clarifiers are used, Figure 5. The diameter of the flocculation tank is $11 \mathrm{~m}$ and depth of water in the tank is $5.5 \mathrm{~m}$ as well.

\subsubsection{Sedimentation Process}

Sedimentation is one of the most basic processes of water treatment (Lin and Lee, 2007). Sedimentation is recommended as simple and low-cost pre-treatment in which removes undesirable small particulate suspended matters (sand, silt, and clay) and some biological contaminants from water under the influence of gravity (Jahanshahi and Taghizadeh, 2018). The total depth of the sedimentation tank is 4 to $5.5 \mathrm{~m}$, Figures 5.

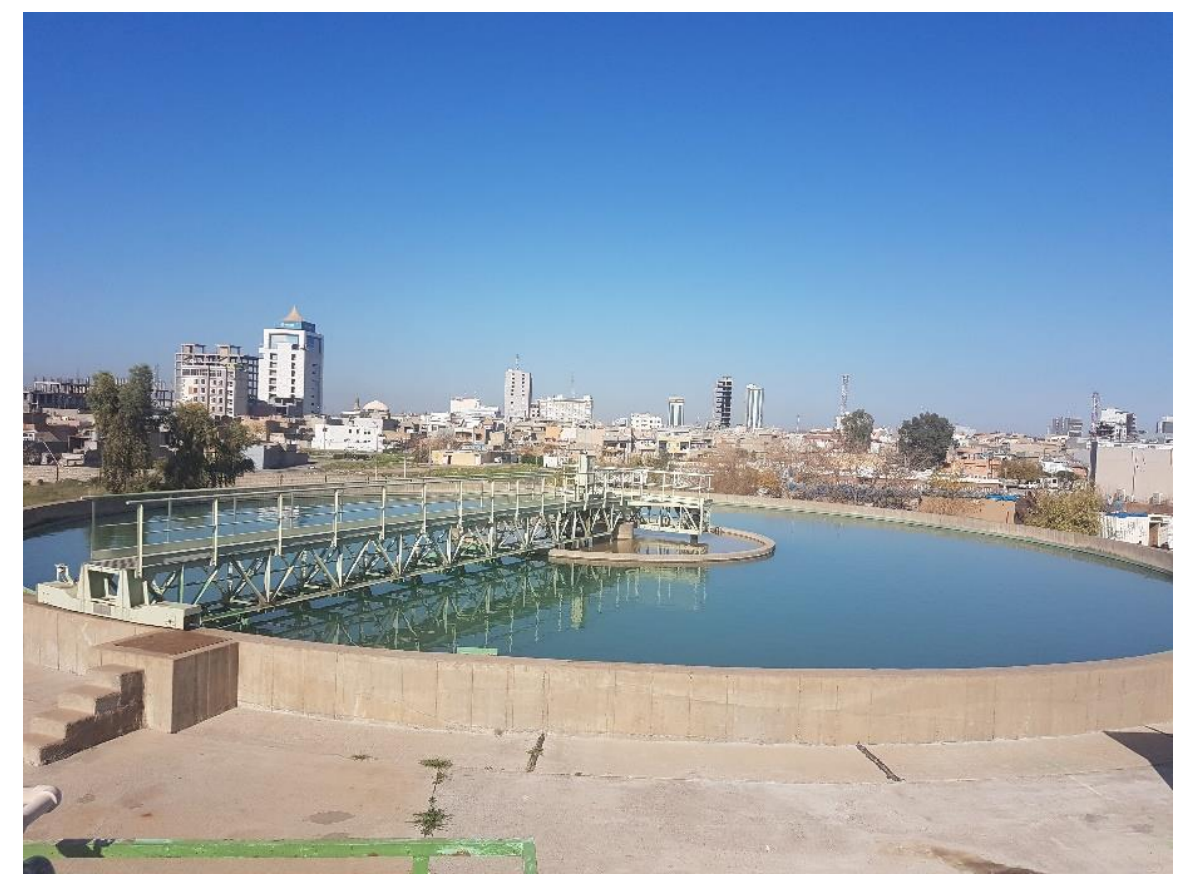

Figure 5: Sedimentation tank with flocculation unit 


\subsubsection{Filtration Unit}

Filtration is the final part of removing unsettled floc and suspended particles. The rapid sand filter is the most common filter type that in use. In the sand filter which is consist of layers water move vertically. Effective filtration is that extend to the depth of filter, it accounts as a key working of the filter. If the upper layer of sand blocks whole particles, it will clog faster (Aziz, 2009). In the Ifraz 2 (WTP), water is directed from the sedimentation basins to 12 rapid sand filters by two pipes. The sand has an "effective size" within the range of 0.35 to 0.5 millimeter with a uniformity coefficient of 1.3 to 1.7 . The water flows by gravity. Each pipe feeds 6 filters. Length and width of each filter tank are $8 \mathrm{~m}$ and $6 \mathrm{~m}$, respectively. In Ifraz 2 (WTP) sand with a thickness of $60 \mathrm{~cm}$ is designed as filter media. In some parts of the filter tanks, the thickness reduced to 30 $\mathrm{cm}$ which is cause problem for the filtration process. Air and water are used for the backwashing process. Treated water of 2 to $2.5 \%$ is used for the backwashing of the filters (EWD, 2019).

Filtration rate $=Q_{\text {per filter tank }} /$ area of filter tank

$Q_{\text {per filter tank }}=69120 \mathrm{~m}^{3} /$ day $/ 12=5760 \mathrm{~m}^{3} /$ day $=240 \mathrm{~m}^{3} / \mathrm{h}$. filter

Filtration rate $=240 \mathrm{~m}^{3} / \mathrm{h} /(8 \mathrm{~m} \times 6 \mathrm{~m})=5 \mathrm{~m}^{3} / \mathrm{m}^{2} . \mathrm{h}=5 \mathrm{~m} / \mathrm{h}$

Filtration rate of $5 \mathrm{~m} / \mathrm{h}$ is in the range reported in literature (Aziz, 2000; Davis, 2010).

\subsubsection{Disinfection/Chlorination}

The object of chlorination is to disinfect the filtered water to make it suitable for portable use (Mishera, 2014). Chlorine is added to the process to kill and inactivate any remaining pathogens (Angreni, 2009). In Ifraz 2 (WTP) and after the filtration stage, the filtered water passes to the disinfection unit. Chlorine gas is added before the storage and distribution of treated water. After the disinfection step, water is ready to pump into the network to distribute to the homes and business places.

\subsubsection{Storage and other facilities}

After the water has been purified in the treatment plant, it will store in the large underground tank with a capacity of $3000 \mathrm{~m}^{3}$. Then from reservoir water is directly pumped to the water distirbution system using 6 pumps with a capacity of $690 \mathrm{~m}^{3} / \mathrm{h}$ (EWD, 2019). 


\subsection{8 (WTP) Laboratory}

Ifraz 2 (WTP) has a laboratory to confirm that the water treatment process had been done properly and water is safe for drinking. There are daily tests chemically and biologically for water by taking different parameters, and it is done on-line monitoring process. They conducted daily Jar test for choosing the optimum dosage of coagulant for the coagulation process. Chloride, $\mathrm{pH}$, alkaline, hardness, conductivity, turbidity etc. are measured in the laboratory. In addition, drinking water samples from various areas and sources are analyzed in the Ifraz 2 (WTP) laboratory.

\subsubsection{SCADA System}

Supervisory control and data acquisition (SCADA) refers to virtually any data acquisition system, but usually, one which exercises monitoring and supervisory control of a number of sites from a control center. Such systems are widely used in the water industry so that a 24 hour manned control center can react to any problems arising at sources or throughout a water production facility or a water distribution system (Brandt et al ., 2016). In Ifraz 2 (WTP) there was a SCADA room which has several duty such as controlling and monitoring all the parts and units of the project, input flow, pumps operation and how long it works, storge water tank level, input raw water turbidity, before and after filtration turbidity, and output turbidity, Figure 6.

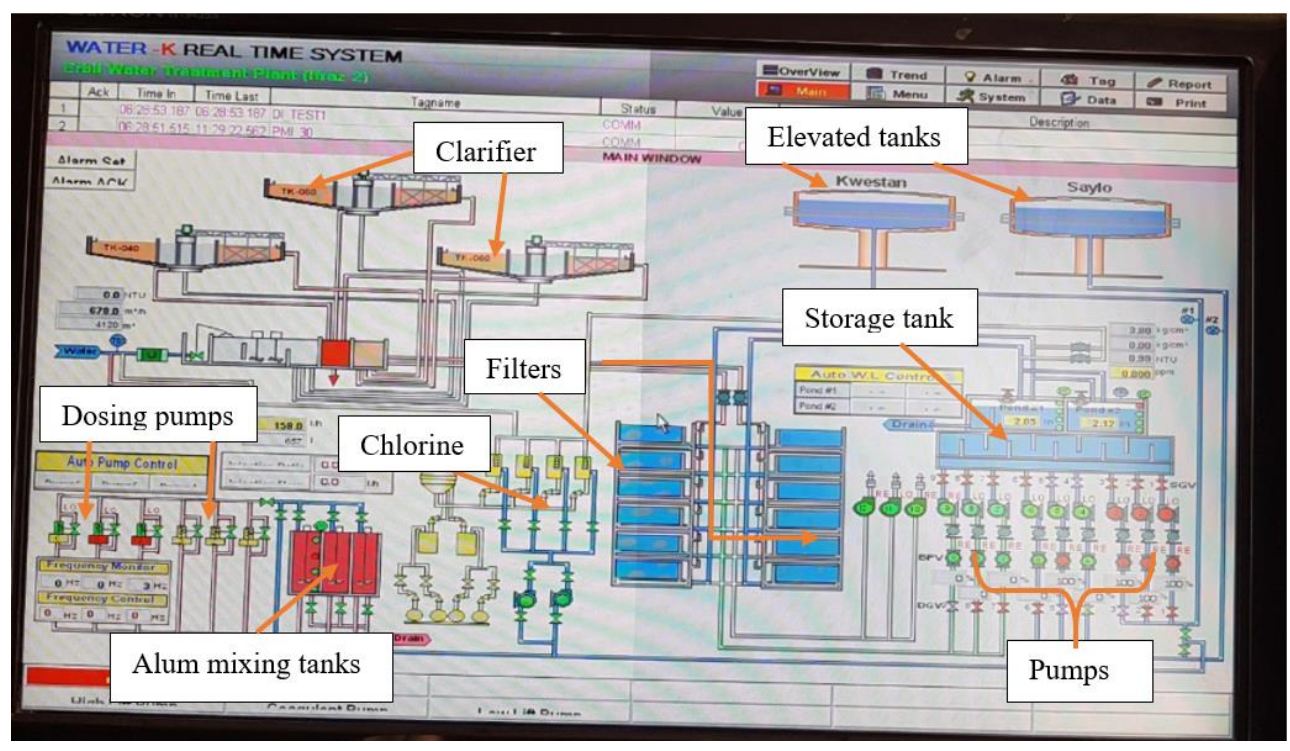

Figure 6: SCADA system 


\subsection{Performance of (WTP)}

In order to assess the water treatment plant efficiency of Ifraz-2 (WTP), twenty samples were taken from November 2018 to March 2019. The aim was to measure the turbidity parameter after each unit process and measured the efficiency of each unit and the whole (WTP). The results for sedimentation basin, filtration unit, and storage units are presented in Table 3. Removal efficiency for the units and the entire (WTP) was determined using Eq. 1.

Removal efficiencies for the sedimentation unit, filtration unit, and disinfection unit are shown in Figure 7. Maximum and minimum removal efficiencies for sedimentation unit were $99.34 \%$ and $60.81 \%$, respectively. The overall proportion of the total basin sedimentation was 91.51\%. Mohammed and Shakir (2012) observed the overall removal efficiency of sedimentation basin $46 \%$ in Al-Wahdaa Project Drinking (WTP) in Baghdad. In addition, Mahinge and Khedikar (2016) stated that the overall turbidity removal in clariflocculator was $77.30 \%$ at a Midc Hingna (WTP) in India. It can be noticed that a great part of the settleable solids removed in Sedimentation stage in the Ifraz 2 (WTP).

Table 3: Turbidity value for the collected samples

\begin{tabular}{|c|c|c|c|c|c|c|c|}
\hline No. & Date & $\boldsymbol{p H}$ & Temperature & $\begin{array}{c}\text { Inlet } \\
\text { Turbidity } \\
\text { NTU }\end{array}$ & $\begin{array}{c}\text { After } \\
\text { Sedimentation } \\
\text { NTU }\end{array}$ & $\begin{array}{c}\text { After } \\
\text { filtration } \\
\text { NTU }\end{array}$ & $\begin{array}{c}\text { Storage } \\
\text { Tank } \\
\text { NTU }\end{array}$ \\
\hline 1 & $01 / 1 / 2018$ & 7 & 18.0 & 825 & 7.7 & 4.4 & 5.6 \\
\hline 2 & $11 / 11 / 2018$ & 7.07 & 17.6 & 1926 & 12.8 & 5.4 & 4.9 \\
\hline 3 & $18 / 11 / 2018$ & 7.12 & 17 & 670 & 14 & 5.0 & 3.7 \\
\hline 4 & $25 / 11 / 2018$ & 7 & 16 & 1000 & 15.6 & 2.8 & 1.2 \\
\hline 5 & $03 / 12 / 2018$ & 6.9 & 15 & 1780 & 23.8 & 6.2 & 7.3 \\
\hline 6 & $09 / 12 / 2018$ & 7.13 & 14 & 640 & 11.1 & 3.93 & 5.2 \\
\hline 7 & $17 / 12 / 2018$ & 7.44 & 13 & 192 & 12 & 4.1 & 3.2 \\
\hline 8 & $26 / 12 / 2018$ & 6.84 & 13 & 200 & 14.9 & 2.3 & 3.3 \\
\hline 9 & $02 / 01 / 2019$ & 7.4 & 12 & 242 & 11 & 4.5 & 6.6 \\
\hline 10 & $13 / 1 / 2019$ & 6.89 & 10 & 51.8 & 20.3 & 4.3 & 3.9 \\
\hline 11 & $21 / 1 / 2019$ & 7.75 & 11 & 68.3 & 23.4 & 7.1 & 9.7 \\
\hline 12 & $30 / 1 / 2019$ & 6.6 & 13 & 1978 & 29.9 & 3.2 & 2.4 \\
\hline 13 & $03 / 02 / 2019$ & 6.83 & 14.0 & 684 & 10.3 & 4.5 & 5.4 \\
\hline 14 & $07 / 02 / 2019$ & 7.02 & 14 & 157 & 9.49 & 4.4 & 3.2 \\
\hline 15 & $17 / 2 / 2019$ & 7.33 & 14.1 & 292 & 15.9 & 4.3 & 3.2 \\
\hline 16 & $26 / 2 / 2019$ & 6.89 & 14.2 & 64.3 & 12.4 & 4.1 & 4.0 \\
\hline 17 & $04 / 03 / 2019$ & 7.5 & 13.5 & 95 & 11 & 5.3 & 3.5 \\
\hline 18 & $17 / 3 / 2019$ & 7.39 & 12.8 & 283 & 10 & 3.0 & 3.0 \\
\hline 19 & $24 / 3 / 2019$ & 7.64 & 14.4 & 75 & 15 & 6.0 & 6.0 \\
\hline 20 & $31 / 3 / 2019$ & 7.47 & 14.6 & 1000 & 8.75 & 6.19 & 6.3 \\
\hline
\end{tabular}


It is obvious to observe that effective removal of the sedimentation fluctuated during the period of the study due to absent of using an optimum dosage of coagulation, especially in 3/12/2018, 21/1/2019, 13/1/2019, and $30 / 1 / 2019$. The turbidity of water after filtration had reached its highest value on 21/1/2019 with a total value of 7.1 NTU and lowered on 26/12/2018 with a total value of $2.3 \mathrm{NTU}$. The mean of the turbidity passed filtration basin is 4.55 NTU, as shown in Table 4. Mohammed and Shakir (2012) observed the overall rate of turbidity crossed filtration basin 3.4 NTU. However, the removal efficiency of filtration basins had peaked on $30 / 1 / 2019$ with around $89.3 \%$ and it lowered on 31/3/2019 with about 29.6\%. While, Mohammed and Shakir (2012) observed the removal efficiency of filtration with around $86.7 \%$, and it lowered with about $58.23 \%$, which indicates good result compare with Ifraz 2 (WTP). It observed that the rates of removal of the filtration basins are relatively medium with the average of $64.71 \%$ but show some problems when the turbidity entering the filter with water precipitated a high and this is what observed in some samples. Furthermore. There were some real problems in the filtration process due to the shortage of sand filter media, in some filters, the thickness of the sand was less than $30 \mathrm{~cm}$ which affects negatively on the efficiency of the filtration units.

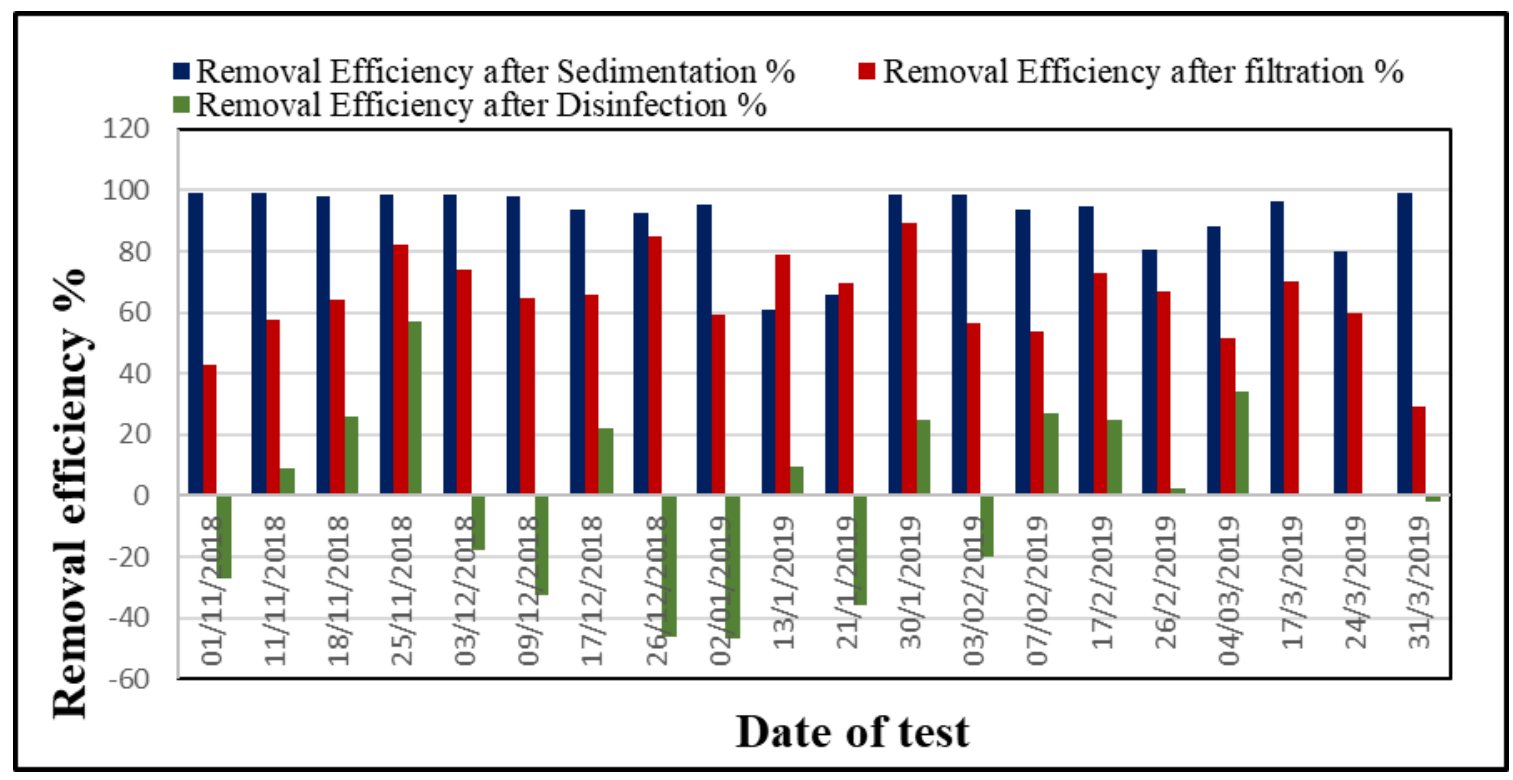

Figure 7: The removal efficiency of different units of (WTP)

In the last stage of storage water after disinfection, it is clear to know from Table 3 that the turbidity of water after disinfection had reached its highest value on 21/1/2019 with a total value of $9.7 \mathrm{NTU}$ and decreased to the lowest value on $25 / 11 / 2018$ with $1.2 \mathrm{NTU}$. The overall rate of turbidity abroad disinfection is $4.58 \mathrm{NTU}$ as shown in Table 4. 
Table 4: Descriptive Statistical Analysis

\begin{tabular}{|l|c|c|c|c|}
\hline & Raw Water Turbidity & $\begin{array}{c}\text { Turbidity after } \\
\text { Sedimentation }\end{array}$ & $\begin{array}{c}\text { Turbidity after } \\
\text { Filtration }\end{array}$ & $\begin{array}{c}\text { Turbidity after } \\
\text { Disinfection }\end{array}$ \\
\hline Mean & 611.1 & 14.4 & 4.55 & 4.58 \\
\hline Std. Deviation & 635.7 & 5.7 & 1.2 & 1.9 \\
\hline Minimum & 51.8 & 7.7 & 2.3 & 1.2 \\
\hline Maximum & 1978.0 & 29.9 & 7.1 & 9.7 \\
\hline
\end{tabular}

It observed that the rates of removal of the disinfection and storage basin is negative in several cases and effect on the purified water in the previous units due to access of solids and silt inside the storage tank, when new water input the tank makes turbulent in the tank and made the bottom mud of the tank mixed with the input water. The average whole removal efficiency of the (WTP) was 97.29\%. Similar values for (WTP) in Khanaqin City-Iraq was reported by Issa (2017).

\subsection{Statiscal Analysis}

The Correlation analysis was conducted for the different treatment units to search for any significant correlation among the examined samples in this study. The correlation results disclosed that statistically there were no significant correlations among treated water samples at a confidence level of $95 \%$ ( $P$-value $>0.05)$ between the units except there was a positive significant correlation between filtration and disinfection units $(\mathrm{P}$-value $=0.00<0.05)$ as shown in Table 5 . This means that there was only a strong correlation between treated water after filtration and after disinfection, while there were no correlations among the other units.

Table 5: Correlations between units

\begin{tabular}{|l|l|c|c|c|c|}
\hline \multicolumn{2}{|l|}{} & $\begin{array}{c}\text { Raw Water } \\
\text { Turbidity }\end{array}$ & $\begin{array}{c}\text { Turbidity after } \\
\text { Sedimentation }\end{array}$ & $\begin{array}{c}\text { Turbidity after } \\
\text { Filtration }\end{array}$ & $\begin{array}{c}\text { Turbidity after } \\
\text { Disinfection }\end{array}$ \\
\hline \multirow{2}{*}{ Raw Water Turbidity } & Pearson Correlation & 1 & .374 & .051 & -.005 \\
\cline { 2 - 6 } & Sig. (2-tailed) & & .104 & .831 & .983 \\
\hline \multirow{2}{*}{ Turbidity after Sedimentation } & Pearson Correlation & & 1 & .096 & .096 \\
\cline { 2 - 6 } & Sig. (2-tailed) & & & .688 & .686 \\
\hline \multirow{2}{*}{ Turbidity after Filtration } & Pearson Correlation & & & 1 & $.795^{* *}$ \\
\cline { 2 - 6 } & Sig. (2-tailed) & & & & .000 \\
\hline \multirow{2}{*}{ Turbidity after Disinfection } & Pearson Correlation & & & & 1 \\
\cline { 2 - 6 } & Sig. (2-tailed) & & & & \\
\hline
\end{tabular}

**. Correlation is significant at the 0.01 level (2-tailed). 
Another test was conducted for the final treated water in the storage tank to test the turbidity by the following hypothesis:

$\mathrm{H}_{0}: \mu \geq 5, \mathrm{H}_{1}: \mu<5$

When:

$\mathrm{H}_{0}=$ Null Hypothesis,

$\mathrm{H}_{1}=$ Alternative Hypothesis,

$\mu=$ Mean of turbidity

Depending on the results in Table 6, it cannot reject the null hypothesis because the P-value is $0.352>\alpha=$ 0.05 , meaning that there are no significant differences between turbidity for the (WTP) samples in the storage tank and turbidity standards 5 NTU. The result is not appropriate because the turbidity of (WTP) may exceed the turbidity standard 5 NTU.

Table 6: One-Sample t-Test

\begin{tabular}{|l|c|c|c|c|c|c|}
\hline & \multicolumn{9}{|c|}{ Test Value =5 } \\
\cline { 2 - 7 } & & & & & \multicolumn{2}{|c|}{$\begin{array}{c}\text { 95\% Confidence Interval of the } \\
\text { Difference }\end{array}$} \\
\cline { 5 - 7 } & $\mathrm{t}$ & $\mathrm{df}$ & P-value & $\begin{array}{c}\text { Mean } \\
\text { Difference }\end{array}$ & Lower & Upper \\
\hline $\begin{array}{l}\text { Turbidity after } \\
\text { Disinfection }\end{array}$ & -0.954 & 19 & 0.352 & -.4200 & -1.341 & 0.501 \\
\hline
\end{tabular}

\subsection{WQI (Water Quality Index)}

The average WQI values for Ifraz-2 (WTP) during the period of the study have been calculated according to the equations in section 2.3 and built a clear and general vision for the physicochemical quality of drinking water produced from this plant during the observation time. The average WQI for Ifraz-2 (WTP) value was 51.87 and fall in good quality. Toma (2013) assessed WQI for water samples from Greater-Zab river and the three ((WTP)s) on Greater-Zab River for a period of four years during 2009 to 2012, the result indicated that WQI of the three (WTP)s is good in 2009 and is excellent in 2012 in respect to drinking uses. Issa and Alrawi 
(2018) conducted a long-term Drinking Water Quality Assessment Using Index for Three (WTP)s of Erbil City, Iraq, results showed that drinking water quality falls within the excellent to good quality.

\section{Conclusions:}

Greater-Zab River water needs treatment prior to use by consumers. Fluctuations of turbidity values for Greater-Zab River water caused problems to Ifraz2 (WTP) units. A great part of solids removed after coagulation-flocculation and sedimentation tanks. Problems found in the sedimentation unit due to absent of using an optimum dosage of coagulation. Bad efficiency of filtration unit because of a shortage of sand bed layer. Availability of settled materials in the storage tanks resulted in increasing turbidity again after the filtration process. Commonly, overall removal efficiency for Ifraz 2 (WTP) was greater than $97 \%$ and the treated water is safe for drinking. Correlation analysis conducted among the different units and revealed that the only correlation between filtration and storage unit was found, and one-sample t-test stated for the treated water in the storage tank and it showed that the turbidity of Ifraz-2 (WTP) may exceed 5 NTU. Drinking water quality assessment has been performed for Ifraz-2 (WTP) during the study period. Drinking WQI result showed that the drinking water quality from Ifraz-2 project falls within the good quality.

\section{References:}

American Public Health Association (APHA), 2005, Standard methods for the examination of water and wastewater, 21st ed. Washington, DC: American Public Health Association.

ANGRENI, E. 2009. Review on optimization of conventional drinking water treatment plant. World Applied Sciences Journal, 7, 1144-1151.

AZIZ, S. Q. Treatment of greater-Zab water by direct filtration. Thirteenth International Water Technology Conference, 2009. Citeseer.

BARUTH, E. E. 2005. Water Treatment Plant Design (; American Water Works Association, and American Society of Civil Engineers. New York: McGraw-Hill.

BRANDT, M. J., JOHNSON, K. M., ELPHINSTON, A. J. \& RATNAYAKA, D. D. 2016. Twort's Water Supply, Butterworth-Heinemann.

CRITTENDEN, J. C., TRUSSELl, R. R., HAND, D. W., HOWE, K. J. \& TCHOBANOGLOUS, G. 2012. $M W H ' s$ water treatment: principles and design, John Wiley \& Sons.

DAVIS, M. L. 2010. Water and wastewater engineering, McGraw-Hill.

DELPHOS, P. J. \& WESNER, G. M. 2005. Mixing, coagulation, and flocculation. Water treatment plant design.

DOOSTI, M., KARGAR, R. \& SAYADI, M. 2012. Water treatment using ultrasonic assistance: A review. Proceedings of the International Academy of Ecology and Environmental Sciences, 2, 96.

FRANK, R. 2003. Spellman Handbook of water and wastewater treatment plant operation.

FOELLMI, S. N. 2004. INTAKE FACILITIES. In: EDWARD E, B. (ed.) Water Treatment Plant Design. Fourth Edition ed. New York: McGRAW-HILL 
HUSSAIN, S., MANE, V., TAKDE, S., PATHAN, A. \& FAROOQUI, M. 2011. Comparison between Treated and Untreated water so as to study water treatment plant of Ahmadpur dist. Latur, Maharashtra.

ISSA, H. M. 2017. Evaluation of water quality and performance for a water treatment plant: Khanaqin city as a case study. Journal of Garmian University, 3, 802-821.

ISSA, H. M. \& ALRWAI, R. A. 2018. Long-term Drinking Water Quality Assessment Using Index and Multivariate Statistical Analysis for Three Water Treatment Plants of Erbil City, Iraq. UKH Journal of Science and Engineering, 2, 39-48.

JAHANSHAHI, M. \& TAGHIZADEH, M. M. 2018. Pre-sedimentation tank effects on water treatment unit operation. EQA-International Journal of Environmental Quality, 28, 35-42.

KHAN, A. A. \& AHMAD, S. K. 2018. PERFORMANCE EVALUATION OF WATER TREATMENT PLANT AT NANGLOI, NEW DELHI: A CASE STUDY IJRET: International Journal of Research in Engineering and Technology

LIN, S. D. \& LEE, C. C. 2007. Water and wastewater calculations manual, Mcgraw-hill New York.

MAHINGE, A. S. \& KHEDIKAR, I. P. 2016. Performance Evaluation of Water Treatment Plant at Midc Hingna, Nagpur: A Case Study in India IJSRD - International Journal for Scientific Research \& Development, 04.

MISHERA, A., AND KADU, P. 2014. Performance Evaluation of Water Treatment Plant at Yavatmal (MS): Case Study. International Journal of Research in Advent Technology, 2, pp. 455-458

MOHAMMED, A. A. \& SHAKIR, A. A. 2012. Evaluation the Performance of Al-wahdaa Project Drinking Water Treatment plant: A case Study in Iraq. International Journal of Advances in Applied Sciences, 1, 130-138.

RAMAKRISHNAIAH, C., SADASHIVAIAH, C. \& RANGANNA, G. 2009. Assessment of water quality index for the groundwater in Tumkur Taluk, Karnataka State, India. Journal of Chemistry, 6, 523-530.

SEFIE, A., ARIS, A. Z., RAMLI, M. F., NARANY, T. S., SHAMSUDDIN, M. K. N., SAADUDIN, S. B. \& ZALI, M. A. 2018. Hydrogeochemistry and groundwater quality assessment of the multilayered aquifer in Lower Kelantan Basin, Kelantan, Malaysia. Environmental earth sciences, 77, 397.

SHAREEF, K. M. \& MUHAMAD, S. G. 2008. Natural and drinking water quality in Erbil, Kurdistan. Current World Environment, 3, 227-238.

TOMA, J. J. 2013. Evaluating Raw and treated water quality of Greater Zab River within Erbil city by index analysis. International Journal of Emerging Technologies in Computational

and Applied Sciences (IJETCAS).

VIEIRA, P., ALEGRE, H., ROSA, M. \& LUCAS, H. 2008. Drinking water treatment plant assessment through performance indicators. Water Science \& Technology: Water Supply, 8.

WANG, L. K., HUNG, Y.-T. \& SHAMMAS, N. K. 2005. Physicochemical treatment processes, Springer.

WHO 2011. Guidelines for drinking-water quality. WHO chronicle, 38, 104-8. 